\title{
THE CONTRIBUTION OF F.W. TAYLOR TO INDUSTRIAL AND ORGANIZATIONAL PSYCHOLOGY *
}

\author{
E.C. THOMAS
}

UITENHAGE

\section{OPSOMMING}

In die artikel word getoon dat F.W. Taylor die erkende "vader van wetenskaplike bestuur" ook erkenning behoort te geniet as grondlegger van die Bedryf en -organisasiesielkunde. Sy werk op die terreine van prestasiemotivering en tevredenheid, opleiding, plasing van werkers, bestuurs- en organisasieontwikkeling en arbeidsverhoudinge het waarskynlik die werk van erkende sielkundiges op hierdie gebiede vooruitgeloop, of grondslag daarvoor gelê. Daar word tot die slotsom gekom dat alhoewel Taylor nie 'n opgeleide sielkundige was nie, hy en sy kollegas erkenning moet kry vir die praktiese implimentering van die beginsels en teorieë van die moderne Bedryf-en Organisasiesielkunde.

Frederick Winslow Taylor, 1856-1915, is commonly referred to as the 'Father of Scientific Management', the principles of which are commonly regarded as antithetical to those of Industrial and Organizational Psychology. The contributions made by Taylor are therefore generally unacknowledged by (and possibly unknown to) Industrial and Organizational Psychologists. These contributions were also potential rather than actual, in that they were not adopted either by practitioners or by the emerging discipline of Industrial and Organizational Psychology.

The basic principles of scientific management, as codified by Taylor (1911) may be summarised as:

- $\quad$ The development of a true science (of work) ;

- $\quad$ The scientific selection of the workman;

- $\quad$ The scientific training and development of the (selected) workman; and

- Intimate friendly co-operation between the management and the men.

\footnotetext{
${ }^{*}$ Requests for reprints should be sent to the author.
} 
(In 1947, Harper and Row published Taylor's works under the title Scientific Management, and this is the work cited in the references. This volume comprises Taylor's paper on Shop Management, first published in 1903, The Principles of Scientific Management, 1911, and Taylor's Testimony before the Special House Committee, 1912. References to Taylor's pioneering work in Scientific Management and Organizational Psychology will be to the original dates of publication, both to indicate their remarkable historical significance, and to facilitate page references; the three papers are separately numbered in the 1947 volume). In this paper it will be demonstrated that in enunciating and codifying these principles, Taylor advocated and adopted most of the tenets of current Industrial and Organizational psychology in respect of performance motivation and satisfaction; selection, training, and development of workers; management and organizational development; and the ultra-modern field of Labour Relations.

\section{PERFORMANCE MOTIVATION}

There can be little doubt that Taylor (1911, p. 119) was the first to advocate the experimental study of behaviour (motivation) in work organizations: "There is another type of scientific investigation which ... should receive special attention, namely the accurate study of the motives which influence men".

Taylor and his associates conducted "experiments", similar to those they had made to discover the laws of metal cutting, fatigue, and the science of various classes of work, to discover the laws of "the motives which influence men". It was recognised however that, in comparison to laws derived from physical (engineering) experiments: "... the laws that result from experiments of this class ... are subject to a larger number of exceptions ... In developing these laws, accurate, carefully planned and executed experiments ... have been made ... Perhaps the most important law belonging to this class, in its relation to scientific management, is the effect which the task idea has upon the efficiency of the workman ... the average workman will work with the greatest satisfaction, when he is given each day a definite task ... to perform in a given time. It is absolutely necessary to pay him a large bonus, or premium, each time he succeeds in doing his task in the given time ... These two elements, the task and the bonus ... constitute two of the most important elements of the mechanism of scientific management" (Taylor, 1911, pp. 119-122). 
In the field of performance motivation, considerable attention is being given to TaskGoal Theory set in an Expectancy (VIE) Theory framework, and a large body of research (mainly laboratory) is accumulating. As a result of such controlled experiments, Pritchard and Curts (1973) and Terborg (1976) come to the conclusion that specific organizational goals, coupled with financial incentives conditional on their attainment, i.e. "the task and the bonus", might be the "one best way" to move workers from low to high performance. Since, to this writer's knowledge, none of the research into cognitive process motivation models actually addresses the psycho-epistemology of the productive and satisfied worker, Industrial and Organizational psychology has in seventy years not developed Taylor's behaviour change technique into a performance motivation theory. Indeed with the falling into disuse of the differential piece-work scheme, Taylor's (1903, p. 64) "Loss in case of failure" has been lost to this technology.

\section{JOB SATISFACTION AND QUALITY OF LIFE}

Since satisfaction is the opposite side of the coin to motivation, Taylor's "first class men" should have been well satisfied, at least in respect of Existence needs (cost insurance freight Alderfer, 1972). The assumed antithesis between Scientific Management and Industrial and Organizational psychology is mainly in respect of Relatedness and Growth Needs (Alderfer, 1972), and more recently in regard to the concept of "Quality of Life". The antipathy of Industrial and Organizational psychologists is perhaps epitomised by McGregor (1960, pp. 38-39): "If the practices of 'Scientific Management' were deliberately calculated to thwart these needs - which of course, they are not - they could hardly accomplish this purpose better than they do".

However, Taylor (1903, p. 30) castigated "bad management" for their "indifference to the individual character, worth, and welfare of their men". Taylor also frequently alluded to the satisfaction engendered by accomplishment of "a large daily task", only achievable by "first-class men" (e.g. Taylor 1903, p. 64). Since the men (or girls) were frequently told they were first-class men, or whether they were achieving that status, this should have contributed to both self-esteem needs and any felt need for achievement, i.e. egoistic needs.

The "Human Relations" school is popularly regarded as being founded in the Hawthorne experiments (Roethlisberger and Dickson, 1961). It is interesting to compare this report on the work of Elton Mayo with Taylor's reports (1903, pp. 85-91; 1911, pp. 86-87) on 
the systemization of "bicycle ball inspection" at Symonds Rolling Machine Company, Fitchburg Mass., at least 30 years earlier. Taylor (1903, pp. 98-91) reports: "The hours of work were shortened from $10 \frac{1}{2}$ per day, first to $91 / 2$, and later to $81 / 2$; a Saturday half holiday being given them even with the shorter hours. Two recesses of ten minutes each were given them, in the middle of the morning and after-noon, during which they were expected to leave their seats, and were allowed to talk.

... Piece-work was then introduced, a differential rate being paid, not for an increase in output, but for greater accuracy in the inspection; ...

The work of each girl was measured every hour, and they were all informed whether they were keeping up with their tasks, or how far they had fallen short; and an assistant was sent by the foreman to encourage those who were falling behind, and help them to catch up ...

A more interesting illustration of the effect of the improved conditions and treatment is shown in the following comparison ...

ten girls did on an average each day in September, on piece-work, when only working 81/2 hours per day, 2.42 times as much, or nearly two and one-half times as much, in a day ... as they had done when working on day work in March with a working day of 101/2 hours".

Taylor (1911, pp. 95-96) further reports: "The good that came to the girls was -

- $\quad$ That they averaged from 80 to 100 per cent higher wages than they had formally received.

- Their hours of labour were shortened form $101 / 2$ to $81 / 2$ per day, with a Saturday half holiday. And they were given four recreation periods properly distributed through the day, which made overworking impossible for a healthy girl.

- $\quad$ Each girl was made to feel that she was the object of especial care and interest on the part of the management, and that if anything went wrong with her she could always have a helper and teacher in the management to lean upon" (Emphasis added).

Unlike Mayo, Taylor thus ascribes the '2.42 times' increase in productivity not only to the 'especial care and interest', but also to the rest pauses, the incentive scheme, and especially the differential rate. The relay assembly emperiment at Hawthorne essentially replicated the Fitchburg experiment, but Mayo and Roethlisberger consistently ignored causes other than 'Human Relations', especially the incentive and rest pauses, to explain the $32 \%$ (1,32 times) increase in productivity. 
Taylor (1911, p. 138) was also concerned lest the vastly increased earnings under Scientific Management caused a deterioration in the character of his 'first-class men': "the sixty per cent increase in pay which he received was not the result of an arbitrary judgement of a foreman or superintendent, it was the result of a long series of careful experiments impartially made to determine what compensation is really for the man's true and best interest".

Taylor (1903, p. 74) had enquiries made about the pig-iron handlers and shovellers receiving the 60 per cent premium, and reports that only two were intemperate drinkers, and all were leading a better life.

That this latter is a value judgement is irrelevant; the whole modern concept of quality of life is saturated with such value judgements, and usually of the observer rather than the actor. Taylor's concern for the worker's home life; his principles (1911, p. 140) of "harmony not discord"; the fourth principle of scientific management; and especially, his insistence of the development of each worker to his greatest efficiency and prosperity after scientific selection and placement; all these put Taylor in the van of practitioners and psychologists concerned with the worker's quality of life.

\section{SELECTION, TRAINING, AND DEVELOPMENT OF WORKERS}

In the second principle, Taylor, perhaps unwittingly, and certainly unacknowledged, laid the cornerstone of modern Personnel Psychology. That this could have been a true foundation is evidenced by his description $(1911$, p. 89) of the scientific selection of the girls involved in the "Fitchburg experiment" on bicycle ball inspection.

"In the Physiological departments of our universities experiments are regularly conducted to determine what is known as the "personal coefficient" of the man tested. This is done by suddenly bringing some object, the letter A or B for instance, within the range of vision of the subject, who, the instant he recognizes the letter has to do some definite thing, such as to press a particular electric button. The time which elapses from the instant the letter comes in view until the subject presses the button is accurately recorded by a delicate scientific instrument.

Men of ... slow perception and slow action have a high "personal coefficient". (It was) soon recognized that the quality most needed for bicycle ball inspectors was a low "personal coefficient". 
Taylor ascribed the success of the Fitchburg experiment mainly to this scientific selection; the criteria on which he judged this success was not only the 2,42 increase in quality, but also that (1903, p. 90) "the accuracy of inspection under piece-work was one third greater than that under daywork". Taylor obviously had no trouble with the "Criterion Problem" (cf. Smith, 1976) that has since then plagued Personnel Psychologists. Elsewhere (Thomas 1982), the present writer has advocated the validation of Work Study measurement of effort and performance to overcome the lack of valid constructs for these in I/O psychology (Campbell and Pritchard, 1976, p. 92). This affects criterion measurement as well as Expectancy/Task-Goal Theories. Taylor's work is universally acknowledged as the foundation of modern Work Study. The above work on personnel selection may have preceded Muensterberg's selection of streetcar drivers in Boston, and so Taylor may well be the unacknowledged founder of Personnel Psychology.

The training and development of workers subsequent to selection was based on elemental Time Study. Taylor and his associates, in developing the "true science" of work, identified the methods used and time taken by "first-class men" for each small element of work. Training to achieve first-class times by specified methods might nowadays be described as Criterion-Referenced Instruction based on skills analysis. By these means Taylor was able to develop men to their highest potential level, so that for example, those unfitted mentally and physically for the large daily task (471/2 tons) of pig-iron handling were enabled to do the work formally done by skilled machinists. The latter in turn became "functional foreman", mostly "speed bosses", or the training resource person for speed and method training for the upgraded labourers now operating machines.

Taylor (1903, p. 63) felt that management was destined to become an art, and was undoubtedly the first to recommend the situational or contingency approach to management (cf. Luthans, 1975): "Management will be studied as an art and will rest upon well recognized, clearly defined, and fixed principles instead of depending upon more or less hazy ideas received from a limited observation of the few organizations with which the individual may have come in contact. There will, of course, be various successful types, and the application of the underlying principles must be modified to suit each particular case".

Taylor (1903, p. 62) was also convinced that "There is no question that a good organization with a poor plant will give better results than the best plant with a poor organization". 
Taylor (1911, p. 63) also quotes "one of the most successful manufacturers in this country" as saying "If I had to choose now between abandoning my present organization and burning down all of my plants which have cost me millions, I should choose the latter. My plants could be rebuilt in a short time with borrowed money, but I could hardly replace my organization in a generation".

Person (Taylor, 1947, p. xiv) in his preface to the 1947 reprint of Taylor's papers, states that in Taylor's work "every worker was a participant observer in the development of standards". Lawler and Rhode (1976, p. 179) state that such participation is necessary to avoid dysfunctional behaviour. There was apparently as much "concern for people" as "concern for production" in Taylor's approach to management and organization, despite the popular stereotype of the "Scientific Manager".

\section{LABOUR RELATIONS}

In Taylor's philosophy, friendly cooperation between management and men, and the equal division of responsibility (for productivity) between them, was the very foundation of the organization of work and the management art; and "relations between employers and men form without question the most important part of this art" (Taylor, 1903, p. 21).

In South Africa, evidence of the current concern for this "most important part" may be adduced from the establishment of a chair in Industrial Relations at the University of Port Elizabeth; the existence of a similar chair in UNISA's School of Business Leadership; and the establishment of "Labour Relations" sections in many Personnel departments.

Taylor (1903, pp. 118-119), in describing his management system of "functional foremanship", advocated the setting-up of an "Employment Bureau" for the selection and placement of workers, and a "Shop Disciplinarian" closely associated with the bureau. The latter was to concern himself with lateness and absence, wage rates, especially of unsatisfactory workers, and all those matters concerned with the direct relations between management and men, relieving all other functional foremen of these responsibilities.

This appears to be the very essence of modern shop-floor Personnel Management and Labour Relations practice. 


\begin{abstract}
This article demonstrates that Frederick Winslow Taylor, acknowledged "Father of Scientific Management", also merits acknowledgement as the spiritual if not actual founder of Industrial and Organizational Psychology. His work in performance motivation and satisfaction; selection, training, and placement of workers; management and organizational development; and in labour relations is shown probably to have preceded that of acknowledged psychologists in these several fields. It is proposed that, whilst not a trained psychologist, Dr. Taylor should be recognized for advocating, and with his colleagues, practising most of the principles and tenets of modern Industrial and Organizational psychology.
\end{abstract}

\title{
REFERENCES
}

Alderfer, C. Existence, Relatedness, and Growth: Human Needs in Organizational Settings. New York: The Free Press, 1972.

Campbell, J.P. \& Pritchard, R.D. Motivation Theory in Industrial and Organizational Psychology, in Dunnette, M.D. (Ed.) Handbook of Industrial and Organizational Psychology. Chicago: Rand-McNally, 1976, 63-130.

Lawler, E.E. \& Rhode, J.G. Information and Control in Organizations. Pacific Palisades, California: Goodyear, 1976.

Luthans, F. Introduction to Management: A Contingency Approach. New York: McGrawHill, 1976.

McGregor, D. The Human Side of Enterprise. New York: McGraw-Hill, 1960.

Pritchard, R.D. \& Curts, M.I. The influence of Goal Setting and Financial Incentives on Task Performance. Organizational Behavior and Human Performance. 1973, 10, 175-183.

Roethlisberger, F.J. \& Dickson, W.J. Management and the Worker. Cambridge, Mass.: Harvard University Press, 1961.

Smith, P.C. Behaviours, Results and Organizational Effectiveness: The Problem of Criteria, in Dunnette, M.D. (Ed.) Handbook of Industrial and Organizational Psychology. Chicago: Rand-McNally, 1976, 745-775.

Taylor, F.W. Scientific Management. New York: Harper \& Row, 1947.

Terborg, J.R. The Motivational Determinants of Goal Setting. Journal of Applied Psychology. 1976, 61(5), 613-621.

Thomas, E.C. An Empirical Test of an Eclectic Theory of Performance Motivation and Satisfaction. University of South Africa, unpublished Masters Dissertation, 1982. 